\title{
Analysis of Technical, Allocative And Economic Efficiency In Maize Production In Ethiopia Evidence From Low Land of Gudeya Bila : Stochastic Frontier Approach
}

Tolesa Tesema ( $\nabla$ tolesatesema2@gmail.com )

Wollega University, Ethiopia

Research

Keywords: Cobb-Douglas, Efficiency, Smallholders farmers, stochastic frontier and Tobit

Posted Date: August 18th, 2021

DOI: https://doi.org/10.21203/rs.3.rs-792476/v1

License: (9) This work is licensed under a Creative Commons Attribution 4.0 International License.

Read Full License 
Analysis of technical, allocative and economic efficiency in maize production in Ethiopia evidence from low land of Gudeya Bila : Stochastic frontier approach

Tolesa Tesema: Department of Agricultural Economics, Wollega University, Ethiopia, P.O. Box 395

Email:tolesatesema2@gmail.com

\section{Abstract}

Traditionally farming system of rural area in Ethiopia is based on producing maize without oxen ploughing which is characterized with clearing land by their own land and cultivating it without oxen ploughing. Thus for many years the farmers of Ethiopia are unable to meet their food security. This situation is continued currently in the study area in which the production system of maize is based on producing advanced methods of production that need improvements of efficiency of farmers .Therefore these studies analyze economic efficiency and constraints of maize production under shifting in the low land farming of Gudeya Bila district. The study was conducted using cross-sectional data collected during the 2020/2021 production year from 154 randomly selected sample households. To estimate the level of technical, allocative and economic stochastic production frontier model was employed and Tobit model was used to identify factors affecting technical, allocative and economic efficiency of sample households. The mean technical, allocative and economic efficiency were $78.78 \%, 69.99 \%$ and $56.66 \%$ respectively. The Tobit model results shows that education levels, family size, farm size, construction of terrace, frequency of extension contact, uses of credit, participation in off/non-farm activities and shifting cultivation had a significant positive effect on technical efficiency. Livestock holding and participation in off/nonfarm activities have positive effects and distance to plot were found to have negative effect on allocative efficiency while family size, soil conservation practice, credit, extension service, off/non-farm activities were found to have positive effect and distance to plot is negative influence on economic efficiency. The main conclusion steaming from this analysis was there is the possibility to enhance the efficiency of maize producers in the study area. Thus policies and strategies of the government should be directed towards the contraction of terrace, shifting from shifting cultivation to oxen farming, producing by fragmented of land rather than focusing only on single plot.

Key words: Cobb-Douglas, Efficiency, Smallholders farmers, stochastic frontier and Tobit 


\section{Introduction}

Agriculture in Ethiopia was prevailing in bringing down poverty. Nevertheless; vulnerability of returning to poverty remains high, particularly for rural livelihoods dependent on rained agriculture (World Bank, 2016). More ever agriculture in most developing countries is stagnant due to inefficiency in farm production that was not able to meet available food demand (Abdul, 2013). Similar to most developing countries Ethiopia is one of the struggler in terms of agricultural production efficiency in the face of ever rising population growth rate that is unable to fulfill the need of local community(Nandeeswara and Bealutukela, 2015).Farming techniques have changed little over the centuries yielding low outputs and making farmers vulnerable to the effects of unpredictable weather patterns (ATA, 2016; Tefaye and Beshir, 2014).The Ethiopian government initiated new extension programs which had given the main concern to maize over long periods of time for the reason that its known ability to respond positively to improved inputs and the opportunity of achieving dramatic growth in productivity (Samuel, 2006). Even if maize is an important food crop and the efforts made so far to generate and disseminate improved technologies, its productivity remains below its potential. Increment of productivity and production of agricultural sector by using improved technologies can be high if there is improvement of the existing level of efficiency of farmers (Asefa, 2011).Moreover it is not sufficient to meet national requirement of production by only yield-enhancing agricultural technologies in the country (Tura et al., 2010 ;Sorsie et al., 2015 and Kitila and Alemu, 2014).Consequently if farmers are producing to supply the surplus to the market after feeding themselves with reducing land per capita due to population growth, they need to adopt new farming practices and increase their efficiency (Jema, 2008;Geta et al., 2013 and Alelign, 2017).Thus is study intended to feel the gap in the

study area by analyzing the levels of small holder farmers economic efficiency and by identifying the factors affecting economic efficiency of smallholder farmer's in the study area.

\section{Research Methodology}




\section{Description of the Study Area}

This study was carried out in low lands of Gudeya Bila district, which is one of the 17 districts located in the northeastern part of East Wollega zone. The district has a total estimated population of 71629 of whom $49.2 \%$ are men and $50.8 \%$ are women; and $86.85 \%$ of its population is rural dwellers. The farming system in the district is mainly mixed croplivestock production. Most farmers in the district undertake both crop production and livestock rearing activities. Agriculture is mainly characterized by rain-fed production system. Maize is one of the major cereals grown in the low lands of the district in which farming is mostly with limited oxen.

\section{Sampling techniques and Sample size determination}

Two stage random sampling techniques was used for this the study to select sample respondent. In the first stage three Kebeles of namely Zangi, Gute Chancho and Abay Dale were purposively selected from the district since they are low land of the district and maize is the dominant crop grown in the study area. In the second stage 60, 24 and 70 sample household was selected by simple random sampling from three kebeles.Finally 154 households that produce maize were selected by probability proportional to sample size. The households were selected for survey and sample size was determined based on the formula given by Yemane (1967).

\section{Sources and method of data}

Primary data was collected through cross-sectional survey from 154 households with information collected at household level in low land of the district. Also Secondary data was collected from different journal, internet, published research, and bureau of agriculture of the district. The research will adopt cross-sectional survey as in opposition to time series/panel data primarily due to lack of repeated measurement, cost and time implications. Crosssectional survey enables to collect data at a point in time; it is cost-effective and time saving (Kothari, 2004).This research employed cross-sectional survey using structured questionnaire, 
field observation and focus group discussions in the low land area. Structured questionnaire was used to generate information at household level. The data to be collected include household level output of maize in low land area, the inputs used in the production process and the socioeconomic, demographic, institutional and farm-specific characteristics, input price, cost of input incurred during maize production period such as amount and cost of labour used, rental cost of land, cost of oxen used, and cost seed and fertilizer.

\section{Specification of Model for efficiency and determinants of efficiency in the low land of the study area}

Following Aigner et al. (1977) and Meeusen and van Den Broeck (1977), the stochastic frontier model model is defined as:

$Y_{i}=f\left(X_{i} ; \beta\right)+v_{i}-u_{i}$

Where $Y_{i}$ measures the quantity of maize output of the $i^{\text {th }}$ farm in low lands of the district, $X_{i}$ is the vectors of explanatory variables used by the farmer $\mathrm{i}^{\text {th }}$ in the low land such as land,labor,urea fertilizer ,NPS fertilizer, oxen and seed used by sample household.

The $\beta$ is the vector of unknown parameters. The functional specification $f\left(X_{i} ; \beta\right)$ is a suitable production function (Cobb-Douglas). The disturbance term $v_{i}$ is intended to capture

the effects of the stochastic noise and it is assumed to be $v_{i} \sim \mathrm{N}\left(0, \delta^{2}\right)$. The disturbance, ui, captures the technical inefficiencies.

According to Sharma et al. (1999), the above cost measures are used to estimate the technical, allocative and economic efficiencies respectively. We can define the farm-specific technical efficiency in terms of observed output (Yi) of low land maize to the corresponding frontier output $\left(\mathrm{Yi}^{*}\right)$ using the existing technology.

$T E i=\frac{Y_{i}}{Y^{*}}$

The farm specific economic efficiency is defined as the ratio of minimum observed total Production cost $\left(\mathrm{C}^{*}\right)$ to actual total production cost $(\mathrm{C})$. 


$$
E E i=\frac{C_{*}}{C}
$$

Following Farrell (1957), the allocative efficiency index can be derived from Equations (1) and (2) as Follows:

$$
A E=\frac{E E}{T E}
$$

After estimating the level of technical, allocative and economic efficiency from Stochastic production frontier they were regressed using a censored Tobit model on farm specific explanatory variables that was explain variation in efficiency across farms. As the distribution of the estimated efficiencies is censored from above at the value one, Tobit regression (Gujarati, 2004) is specified as:

$E^{*}=\delta o+\delta_{m} Z_{i m}+\mu$

$v / z \approx \operatorname{normal}\left(0, \delta^{2}\right)$

Where $E^{*}$ - latent variable representing the efficiency scores of farm $\mathrm{j}$, $\delta-$ a vector of unknown parameter to be estimated $Z_{i m}-$ a vectors of explanatory variables $\mathrm{m}(\mathrm{m}=1,2, \ldots \mathrm{n})$ for farm household $\mathrm{X} 1=$ Age of household in year $\mathrm{X} 2=\mathrm{Sex}$ which is either male or female $\mathrm{X} 3=$ Education levels in year of schooling $\mathrm{X} 4=$ wild animals consumption of maize ( 1 if consumed and 0 if not consumed) $\mathrm{X} 5=$ Farm size in hectare $\mathrm{X} 6=$ Livestock in tropical livestock unit $\mathrm{X} 7=$ Fertility which is either fertile or infertile $\mathrm{X} 8=$ Shifting cultivation which is either farmers cultivate under shifting or with oxen $\mathrm{X} 9=$ Terrace which is either cultivated land is contracted by terrace or not $\mathrm{X} 10=$ Land fragmentation which is one for one plot zero otherwise $\mathrm{X} 11=$ Extension measured by frequency of extension contact $\mathrm{X} 12=$ Credit which is dummy variables whether farmers receives credit from microfinance institutions such as oromia credit and saving share company and wasasa or not 
$\mathrm{X} 13=\mathrm{Off} /$ non-farm which refers to whether farmers engaged in off/non-farm activities such as handcrafting, petty trading, service renting and resource extraction or not $\mu$ - Error term that is independently and normally distributed with zero mean and variance $\delta^{2}$ Denoting $E_{i}$ as observed variables,

$$
E_{i}=\left\{\begin{array}{ccc}
1 & \text { if } & E_{i}^{*}>=1 \\
0 & \text { if } & E_{i}^{*}<=0
\end{array}\right\}
$$

\section{Results and discussion}

\section{Maize Production constraints}

Effect of wild animals such as monkey and ape are common the low land of the district since it is the major problem that farmers were facing in the study area which is the 25.32 percent .In the low land about 16.25 percent of respondents reported soil factor was the problem that they were facing. In addition to this 12.99 percent of the respondent faces poor seed productivity problem in the study area. Farmers also reported that there was labour shortage during peak agricultural production season (Table1)

Table 1.Maize production constraint under shifting cultivation farming system in low land of the study area

\begin{tabular}{lcc}
\hline Variables & Frequency & Percent \\
Problem due to wild animal & 39 & 25.32 \\
Seed productivity problem & 20 & 12.99 \\
Weed infestation & 13 & 8.44 \\
Poor land preparation & 22 & 14.29 \\
Shortage of oxen & 10 & 6.49 \\
Labor constraint & 14 & 9.09 \\
Shortage of land & 11 & 7.14 \\
Soil erosion & 25 & 16.23 \\
$\quad$ Total & 154 & 100.0 \\
\hline
\end{tabular}

Source: descriptive statics result

\section{Descriptive statistics of production function variables}


On average, sample farmers obtained 28 quintal of maize. On average the cultivated land area allocated to maize production (both owned and shared land that may be shared in and shared out) by household was 0.70 hectare and ranged from 0.2 hectare to 3 hectare with a standard deviation of 0.4. The amount of seed that sampled households used were 21.5 kilogram on average. Like other inputs, human and animal labor inputs were also important, given a traditional farming system in the study area. Sampled households, on average, used 80.75 man equivalent labor and 21.6 oxen days for the production of maize during 2020/2021 production season (Table 2).

Table 2.summary of production function variables

\begin{tabular}{lccccl}
\hline \multicolumn{1}{c}{ Variables } & Measurement unit & Mean & $\begin{array}{c}\text { Standard } \\
\text { deviation }\end{array}$ & Minimum & maximum \\
\hline Output of maize in lowland & Quintal & 23.05 & 14.63 & 2 & 90 \\
Local seed maize & Kilogram & 21.5 & 11.6 & 3 & 70 \\
Land allocated for maize & Hectare & 0.80 & 0.4 & 0.2 & 3 \\
Nitrogen phosphorus sulfur & Kilogram & 76.45 & 46.7 & 13 & 300 \\
Oxen used & Oxen day & 21.6 & 10.8 & 0 & 68 \\
Labor used & Man day & 80.75 & 37.47 & 18.6 & 305 \\
\hline
\end{tabular}

Source: Descriptive statics result

From the total of five variables considered in the production function, three variables (seed, land and labor) had a significant effect in explaining the variation in maize yield among farmers. The coefficients of the production function are interpreted as elasticity. Hence, elasticity of output to land, seed and labor are $0.34,0.29,0.18$ respectively suggests that maize production was more sensitive to land. As a result, $1 \%$ increase in amount of land will result in $0.34 \%$ increase in maize production, keeping other factors constant The scale coefficient was calculated to be 1.13 indicating increasing returns to scale (Table 2).This implies that there is potential for maize producers to continue to expand their production because they are in the stage I of the production surface, where resource use and production is believed to be inefficient. This is in line with finding of Abdulai et al. (2013) found that maize production in northern Gana exhibit increasing return to scale.

The dual cost function derived analytically from the stochastic production function is given as follows basis for computing allocative and economic efficiency 
$l C m i=5.8+0.008 \omega_{1}+0.45 \omega_{2}+0.0078 \omega_{3}+0 . .19 \omega_{4}+0.07 \omega_{5}+0.08 \omega_{6}+0.99 Y *$

Where $l C m i$ is cost of producing maize; $\omega_{1}$ refers to the price of seed, $\omega_{2}$ is cost of land; $\omega_{3}$ is cost of NPS; $\omega_{4}$ is cost of UREA; $\omega_{5}$ is cost of oxen; $\omega_{6}$ is cost of labor $Y^{*}$ is output adjusted for any statistical noise; $\mathrm{i}^{\text {th }}$ refers to the $\mathrm{i}^{\text {th }}$ sample household.

\section{Estimation of production and cost functions}

Table 3.Estimation of the Cobb-Douglas frontier production function

\begin{tabular}{|c|c|c|c|c|}
\hline Variables & & $\begin{array}{c}\text { Ordinary } \\
\text { least } \\
\text { square } \\
\end{array}$ & & $\begin{array}{l}\text { Maximum } \\
\text { livelihood } \\
\text { estimation }\end{array}$ \\
\hline & Coefficients & Std. Err & Coefficients & Std. Err \\
\hline Constant & 0.1011 & 0.4823 & $1.0135^{*}$ & 325 \\
\hline Lan seed & $0.3351 * * *$ & 0.1025 & $0.34 * * *$ & 0.089 \\
\hline Lan Land & $0.1940 *$ & 0.1026 & $0.29 * * *$ & 0.10 \\
\hline Lan NPS & 0.0729 & 0.0818 & 0.08 & 0.0706 \\
\hline LNurea & $0.1375^{*}$ & 0.0762 & 0.08 & 0.088 \\
\hline Lan oxen & 0.1301 & 0.0950 & 0.16 & 0.0760 \\
\hline Lan labor & $0.1776^{*}$ & 0.0939 & $0.18^{*}$ & 0.0900 \\
\hline $\mathrm{R}^{2}$ & 0.7213 & & & \\
\hline F statistics & 63.42 & & & \\
\hline$\delta^{2}=\delta_{v}^{2}+\delta_{u}^{2}$ & & & $0.23 * * *$ & 0.0526 \\
\hline$\lambda={ }_{\delta u / \delta v}$ & & & $2.5395^{* * *}$ & \\
\hline $\operatorname{Gamma}(\gamma)$ & & & 86.57 & \\
\hline Log likelihood & & & -44.01 & \\
\hline Sample size & & & 154 & \\
\hline
\end{tabular}

Note: $* * *$ and $* * *$ refers to $10 \%, 5 \%$ and $1 \%$ significance level, respectively.

Source: model result (2021)

\section{Technical, allocative and economic efficiency score}

The result of frontier model revealed that, farmers in the study area were relatively good in technical efficiency than in allocative efficiency and economic efficiency of maize production in low land of the district. The mean technical efficiency level was $78.88 \%$ varies from 40.76 to 98.99 shows that maize producing farmers have an opportunity to efficiently utilize 
resources and hence they could increase the current maize output by $21.12 \%$ using the existing technology. This shows that there is a wide difference among maize producer in their level of technical efficiency. The means allocative efficiency of farmers in the study area was $69.99 \%$ and ranges from $36.76 \%$ to $97.6 \%$ indicating that on average, maize producer farmers can save $30.01 \%$ of their current cost of inputs if resources are efficiently utilized. This shows that there is enormous opportunity to increase the efficiency of maize producers by reallocation of resources in cost minimizing way. As illustrated in the above table 4. The mean economic efficiency level of sample households was $56.66 \%$ with minimum and maximum efficiency scores of $19.9 \%$ and $94.8 \%$ respectively. That is the producer with an average economic efficiency level could reduce current average cost of production by $50.11 \%$ to achieve the potential minimum cost level without reducing output levels (Table 4). Technical efficiency result obtained from this analysis is below the finding of (Kifle, 2017). And above result of (Gosa and Jema, 2016). While allocative and economic efficiency result is below finding of and above finding of (Kifle, 2017).

Table 4.Summary statistics of efficiency score of sample households

\begin{tabular}{llllll}
\hline Variables & Observation & Mean & Std.devation & Min & $\max$ \\
\hline Technical efficiency & 154 & 78.78 & 0.1371 & 40.76 & 98.99 \\
Allocative efficiency & 154 & 69.99 & 0.1697 & 36.76 & 97.6 \\
Economic efficiency & 154 & 56.66 & 0.1807 & 19.7 & 94.8 \\
\hline
\end{tabular}

Source: Stochastic model result (2021)

\section{Determinants of efficiency in maize production in low land of district}

As expected, the sign of education was positive effect on technical at $1 \%$ level of significance. This implying that more educated farmers are more technically efficient than those have relatively less education. This could be because more educated farmers were capable to identify, interpret and react to new information and adopt improved technologies such as improved seed, fertilizers, and planting materials much faster than their counterparts the result indicates education improves the acquisition and utilization of information on improved technology by the farmers. This result was in line with the findings of (Mustefa, 2017; Kitila 
and Alemu, 2014).The coefficient of wild animals consumption of maize crop for technical efficiency and economic efficiency is negative and statistically significant at $10 \%$ and $5 \%$ percent significance level respectively. This implies that wild animals consume maize starting from planting to yield that decrease maize production efficiency in the study area. This variable is new variable of the sudy.The coefficient for livestock holding in Tropical livestock unit was positive and had a significant influence on allocative efficiency at $10 \%$ level. The result reveal that farmers having largest number of livestock holding helps to shifts cash constraint and to satisfy all needs of farmers in the study area. This finding was consistent with the result obtained by (Getachew, 2017; Kifle, 2017, Essa, 2011; Sorsie et al., 2015; Tefaye and Beshir, 2014).The coefficient of farm size had positive relation with technical efficiency at $10 \%$ level of significance. It is measured as total land cultivated by the farmer including those owned and shared in the study area. In this study, it was hypothesized that farm size affects efficiency negatively. As the farm size of farm household increases, the managing ability of him/her will decrease given the level of technology, this lead to reduce the efficiency of the farmer. Unexpectedly, the estimated result not agrees with the expectation. This shows that a household operating on small area is less efficient than a household with large land holding size. This is mainly justified on the view that those farmers with large farm size can better diversify their crops and the better chance for maize to be planted on fertile soils. Additionally farmers with larger area of cultivated land have the capacity to use compatible technologies that could increase the efficiency of the farmer. As a result, with increase farm holding size the technical efficiency of the farmer might increase. This finding was in line with results obtained by (Rao and Bealu, 2015; Gosa \& Jema, 2016; Wudineh \& Endrias, 2016).

The shifting cultivation is negative and significant at 5\% levels of significance on both allocative efficiency and economic efficiency. This relation may be because farmers shift their farm land may be fail to prepare their farm land on time and may faces management problem. Whereas, those farmers who cultivates without shifting cultivations are more efficiency since they may manage their farm land effectively. This implies that as the as farmers applies shifting cultivation on their farm land efficiency decrease. The coefficient of terrace on technical and economic efficiency was significant and positive at $1 \%$ and $10 \%$ respectively. 
According to Jara-Rojas, et al. (2012), soil conservation practices not only increase production and productivity of farm land, but also enhances environmental sustainability. This result is in line with (Getahun 2014; Lemessa, et al., 2017) 
Table 5.Tobit model estimates for determinant of different efficiency

\begin{tabular}{|c|c|c|c|c|c|c|}
\hline & $\begin{array}{l}\text { Technical } \\
\text { efficiency }\end{array}$ & & $\begin{array}{l}\text { Allocative } \\
\text { efficiency }\end{array}$ & & $\begin{array}{l}\text { Economic } \\
\text { efficiency }\end{array}$ & \\
\hline Variables & Marginal effect & Standard error & Marginal effect & Standard error & Marginal effect & Standard error \\
\hline Constant & $0.4357 * * *$ & 0.0661 & $0.7053 * * *$ & 0.0643 & $0.3085 * * *$ & 0.0608 \\
\hline Age & 0.0006 & 0.0012 & -0.0011 & 0.00116 & -0.0006 & 0.0011 \\
\hline Sex & -0.0138 & 0.0263 & -0.0032 & 0.0256 & -0.0039 & 0.0243 \\
\hline Education & $0.0104 * * *$ & 0.0033 & -0.0038 & 0.0032 & 0.0047 & 0.0031 \\
\hline Wild animal & $0.0153 *$ & 0.0082 & -0.0059 & 0.008 & $-0.0162 * *$ & 0.0075 \\
\hline Farm size & $-0.0237 *$ & 0.0133 & -0.0003 & 0.0130 & 0.0156 & 0.0123 \\
\hline $\begin{array}{l}\text { Livestock } \\
\text { holding }\end{array}$ & -0.0042 & 0.0032 & $0.0058 *$ & 0.0031 & 0.0017 & 0.0030 \\
\hline Fertility & -0.0055 & 0.0213 & 0.0076 & 0.0207 & 0.0020 & 0.0196 \\
\hline $\begin{array}{l}\text { Shifting } \\
\text { cultivation }\end{array}$ & -0.0004 & 0.001 & $-0.0020 * *$ & 0.0009 & $-0.0018 * *$ & 0.0009 \\
\hline Terrace & $0.0653 * * *$ & 0.0216 & -0.0106 & 0.0210 & $0.0364 *$ & 0.0199 \\
\hline $\begin{array}{l}\text { Land } \\
\text { fragmentation }\end{array}$ & $0.0065 * *$ & 0.00118 & 0.0056 & 0.0056 & 0.0084 & 0.0053 \\
\hline Extension & $0.0040 * * *$ & 0.0011 & -0.0009 & 0.0011 & $0.0019 *$ & 0.0010 \\
\hline Credit uses & $0.0584 * * *$ & 0.0222 & 0.0029 & 0.0216 & $0.0448 * *$ & 0.0205 \\
\hline Off/non farm & $0.0423 *$ & 0.0223 & $0.0437 * *$ & 0.0217 & $0.0573 * * *$ & 0.0206 \\
\hline Loglikehood & 95.70 & & 99.39 & & 107.45 & \\
\hline
\end{tabular}

Note: $* * *$ and $* * *$ significant at $10 \%, 5 \%$ and $1 \%$ level significance, respectively

Source: Tobit model results (2021) 
As expected the coefficient extension was positive and significantly affected the level of technical, economic efficiencies at $1 \%$ and $10 \%$ level of significance respectively. Extension services are assumed to help in diffusion and adoption of new technologies. In addition this extension Services offer guidance to the farmers related to the use of various resources such as fertilizer and provide consultancy services in managing their scarce resources more efficiently. This result was in-line with (Mustefa, 2014; Hailemaraim, 2015; Musa, 2013).

The result also indicated that credit utilized had a positive sign and statistically significant effect on both technical efficiency and economic efficiency level at 1\% and 5\% level of significance. This suggests that on average households with credit utilized tend to exhibit higher levels of efficiency. This due to the reason that credit utilized allows a household to enhance efficiency by removing money constraints which may affect their ability to apply inputs, implements and farm management decisions on time. Hence use of credit reduces the problem of financial constraints, ensures timely supply and use of inputs and results in increased economic efficiency of the households in the study area. This finding is consistent with the result by (Beshir, 2016; Musa, 2013; Moges, 2017).

In this study the coefficient of off/non-farm activity was positive sign and statistically significant at $10 \%, 5 \%, 1 \%$ level of significance effect with respect to TE, AE, and EE respectively as expected. Off/non-farm activities may affect the efficiency positively for the reason that the income obtained from such activities could be used for the purchase of agricultural inputs, and supplement financing of household expenditures which would entirely dependent on agriculture and reduce cash constraint for timely purchase of agricultural input. In other word availability of off/non-farm income decreases cash constraint and enables households to make timely purchase of those inputs which they cannot provide from the farm income hence increases their efficiency. The result is in line with the findings of (Kifle 2017; Gizachew, 2018)

As expected the coefficient of land fragmentation is positive effect on technical efficiency in the low land of the district. This may be due to the reason that the farmers who cultivates in different 
place survive from the animal effect such as monkey and apes which are affecting the product of maize before harvest.

\section{Conclusion}

The study results revealed that there is a considerable variability in all efficiencies and efficiency score of sample household in the production of maize in the study area since the production is characterized with shifting cultivation. The policy makers should give due emphasis to increase the level of efficiencies of the farmers who are far from the modern information and farming. This is because the use of improved technologies is expensive since farmers have serious financial problem because they are subsistence farmers. If their educational opportunities are improved the efficiency of the framers can be enhanced. Thus government should have designed appropriate policy to provide adequate and effective basic educational opportunities to the those low land population, both formal and non-formal education since those farmers are in remote area of the district there is less attention of the government on providing educational opportunities. Given the mixed farming system in the study area, farmers with more number of livestock were relatively better in the allocative efficiency. Hence, there is a need to design appropriate policy and strategies for improving livestock production systems by solving the shortage of feed which in turn will enhance the efficiency of maize production. Farmers who practice soil conservation practice is were relatively better in the technical and economic efficiency. Hence, there is a need to design appropriate policy and strategies for improving soil conservation practice systems by solving the soil fertility problem of maize production. Also to improve the land status by applying new soil conservation practices on their farm through improved sustainable land management practices especially terrace and soil bund is encouraged. other way may be providing practical attachment training with the current agricultural production and as much as possible decrease ratio of development agents to the number of farmers so as to increase the number of extension contact. This study provides evidence on the role of credit utilization in improving technical and economic efficiency positively through reducing financial limitations farmers face in purchasing inputs in maize production. Therefore, establishing adequate rural finance institutions and strengthening of the available micro-finance institutions to 
assist farmers in terms of financial support through credit are crucial to improve farm productivity. In the study area since monkey and apes affects the product of maize providing controlling mechanism of those animals through tourism is very essential.

\section{Declaration}

Ethics approval and consent to participate: Not applicable

Consent for publication: I have agreed to publish this research work

Authors' contributions: Authors have collected data, analyzed interpreted and wrote the research

Competing interests: Author has no conflict of interest.

Availability of supporting data: No supporting data is available for this study

Funding: No fund is received

Acknowledgements: We gratefully acknowledge Wollega University

Authors' information: Authors' information (optional): Author was from Ethiopia. Author was graduate by Bachelor of Science in agricultural resource economics and management from Wollega University won the gold medal in 2015 and studied Msc in Agricultural economics from Jimma university. Currently served as lecturer in Wollega University for four year.

Acronomy: AE=Allocative Efficiency, EE= Economic Efficiency, TE= Technical Efficiency

TLU=tropical livestock unit

\section{Reference}

Aigner, D., Lovell, C.K. and Schmidt, P., 1977. Formulation and estimation of stochastic frontier production function models. Journal of econometrics, 6(1), pp.21-37.

Alelign Ademe Mengistu, 2017.crop productivity, efficiency and commercialization of smallholder farmers in the highlands of eastern Ethiopia $\mathrm{PhD}$ dissertation submitted to haramaya university.

Asefa, S., 2011. Analysis of technical efficiency of crop producing smallholder farmers in Tigray, Ethiopia.

Agricultural Transformation Agency, 2016.Agricultural annual report of Ethiopia.

CSA (Central Statistical Agency),2013. "Population Projection of Ethiopia for All Regions At Woreda Level from 2014 - 2017," Addis Ababa, Ethiopia. 
Essa, C.M., 2011. Economic efficiency of smallholder major crops production in the central highlands of Ethiopia (Doctoral dissertation).

Ermiyas Mekonnen.2013. economic efficiency of sesame production in selamago district of south omo zone, southern Ethiopia. MSc Thesis, Haramaya University, Haramaya, Ethiopia.

Wollie, G. 2017.Economic efficiency of barley production: the case of smallholder farmers in Meket district, amhara national regional state, Ethiopia. Haramaya university, Haramaya.

Getahun Gemechu Abebe.2014. Off-Farm Income and Technical Efficiency of Smallholder Farmers in Ethiopia. European Erasmus Mundus Master Program, Agricultural Food and Environmental.

Gosa Alemu and Jema Haji. 2016. Economic Efficiency of Sorghum Production for Smallholder Farmers in Eastern Ethiopia: The Case of Habro District. Journal of Economics and Sustainable Development. Vol.7,15

Gizachew, F. 2018 .Allocative Efficiency of Smallholder Wheat Producers in Damot, Journal of food science and quality management, 72, pp. 27-35.

Gujarati, D.2004. Basic Econometrics. McGraw-Hill Companies. Tokyo.

Beshir, H., 2016. Technical efficiency measurement and their differential in wheat production: The case of smallholder farmers in South Wollo. IJEBF, 4(1), pp.1-16.

Hailemaraim Leggesse. 2015. Technical efficiency in teff production: the case of Bereh District of Ethiopia. MSc Thesis, Haramaya University, Haramaya, Ethiopia.

Jema Haji.2008. Economic Efficiency and Marketing Performance of Vegetable Production in the Eastern and Central parts of Ethiopia: Doctoral Thesis Presented to Swedish University of Agricultural Sciences.

Kifle Degefa et al., 2017.Economic Efficiency of Smallholder Farmers in Maize Production in Bako Tibe District, Ethiopia. Vol.7, No.2.

Kitila, G. M., \& Alemu, B. A. 2014. Analysis of Technical Efficiency of Small Holder Maize Growing Farmers of Horo Guduru Wollega Zone, Ethiopia: A Stochastic Frontier Approach. Science, Technology and Arts Research Journal, 3(3), 204-212.

Lemessa, S. D., Yismawu, M. A., Daksa, M. D., \& Watabaji, M. D.2017. Risk Adjusted Production Efficiency of Maize Farmers in Ethiopia: Implication for Improved Maize 
Varieties Adoption. Turkish Journal of Agriculture-Food Science and Technology, 5(9), 1099-1107.

Meeusen, W. and van Den Broeck, J., 1977. Efficiency estimation from Cobb-Douglas production functions with composed error. International economic review, pp.435-444.

Moges dessale, 2017. Technical efficiency in teff production: the case of smallholder farmers in Jamma district, south Wollo zone, Ethiopia. A thesis submitted to the school of graduate studies of Haramaya university

Musa hasen Ahmed.2013. Economic efficiency of smallholder farmers in maize production: the case of arsi negelle district, oromia national regional state, Ethiopia. A thesis submitted to the school of graduate studies of Haramaya university

Mustefa Bati, Mulugeta Tilahun and Raja Kumar Parabathina, 2017. Economic efficiency in maize production in Ilu Ababor zone, Ethiopia. Research Journal of Agriculture and Forestry Sciences, Vol. 5(12), 1-8

Nandeeswara rao $\mathrm{p}$ and Bealutukela.2015. Analyzing productivity in maize production: the case of boricha woreda in sidama zone, southern Ethiopia. International journal of recent scientific research vol. 6, issue, 10, pp. 6984-6989.

Samuel Mburu, Chris Ackello-Ogutu, and Richard Mulwa.2014.Analysis of economic efficiency and farm Size: a case study of Wheat Farmers in Nakuru District, Kenya. Economics research international.

Sharma, K.R., Leung, P. and Zalleski, H.M.1999.The technical, allocative, and economic efficiencies in swine production in Hawaii: A comparison of parametric and nonparametric approaches, Agricultural Economics, 20, 23-35.

Sorsie Deme, Nicolette Matthews and Janus Henning.2015.Analysis of factors affecting technical efficiency of smallholder maize farmers in Ethiopia, Conference Paper.

Tefaye, W., \& Beshir, H.2014. Determinants of Technical Efficiency in Maize Production: The Case of Smallholder Farmers in Dhidhessa District of Illuababora Zone, Ethiopia. Journal of Economics and Sustainable Development, 5(12), 274-284

Tsegaye Yilma and Ernst Berg.2015. Technical Efficiency of Maize Production in Southwestern Ethiopia: In a case of jimma zone. 
World Bank, 2016. Federal democratic republic of Ethiopia priorities for ending extreme poverty and promoting shared prosperity systematic country diagnostic.

Yemane, T. I.1967. Statistics: An Introductory Analysis $2^{\text {nd }}$ Edition. New York, Harper and Row. 